\title{
Assessment of Leadership of a Superior in Polish Enterprises
}

\author{
Monika Sipa, Anna Lemańska-Majdzik \\ Czestochowa University of Technology, Poland \\ lemanska@zim.pcz.pl
}

\begin{abstract}
Changes taking place in today's globalised world force enterprises to focus more attention on the quality of leadership resulting mainly from actions and decisions taken by superiors, heads or managers of organisations. Striving to strengthen their market position and achieve success, enterprises concentrate on looking for solutions that will allow them to stimulate employees to make changes and develop in order to increase the quality of the functioning of human capital, and thus implement the strategy of the organisation. Effectiveness and quality of leadership depend to a large extent on competences of employees in an organisation, in particular the competences of the managerial staff. The paper presents results of a survey conducted in January 2015 on a group of employees of Polish enterprises. The aim of the paper is to indicate the main characteristics of a superior and their leadership skills in the area of managing employees. It also points out relationships between selected characteristics and the scale and profile of a company's activity, how long it has been functioning on the market and the period of employment of those surveyed.
\end{abstract}

Keywords: Manager, Superior, Employee, Leadership

\section{Introduction}

Recognising the importance of human resources and their needs in the aspect of activity of an organisation is nothing new - as confirmed by the development of the behavioural discipline in management as early as at the beginning of the 20th century. Modern enterprises that are looking for ways to implement their objectives and build their market position cannot ignore such an important potential as human resources. An organisation is created by its employees whose commitment to the implementation of objectives and whose competences constitute the highest and most valuable capital of an organisation. Functioning and achieving successes in a chaotic and turbulent market environment (Kubik, 2012) depends to a large extent on the competences of employees in an organisation - and in particular on the competences of the managerial staff (Tomaszuk, 2013), that are responsible for coordination of various, key resources: financial, material and human ones (Jarmołowicz \& Kościński, 2005; Okręglicka, 2012). Superiors' attitude and quality of their work constitute the main driving force behind the performance of tasks assigned to employees. That's why managers' leadership skills are so important. Leadership supports the development of an organisation's growth strategy and helps an organisation and its employees to focus on the most important issues. Every employee would like to have a great superior-leader from whom a lot can be learnt. Unfortunately, this is not always the case. As McKee (2014) stresses, "there are a lot of bad managers across the world who are not stupid but lack emotional intelligence." Goleman et al. (2001) point out that most employees "suffer" due to "toxic" behaviour of their superiors-leaders. This has a negative impact on employees' attitude to the tasks they perform and their ties with the organisation.

Although some modern enterprises indicate the use of tools allowing their employees to express their opinions about their superiors, this is not a widespread practice. Employees are much more willing to share their opinions when the procedures within an organisation are fair, and they are more committed and believe that their superior is an open and flexible person (Landau, 2009). Thus, among the most important success factors of modern enterprises are both employees and managers, whose proper qualifications and professional predispositions determine success of entities. This refers to both large corporations and SMEs. Managers and employees of companies create their intellectual resources, increasing enterprises' internal potential, especially their knowledge (Niklewicz-Pijaczyńska \& Wachowska, 2012). In view of the above, the authors of the paper made an attempt to indicate relationships between how the superior is perceived and the size of an enterprise, how long it has been functioning on the market and the profile of its activity. A 2015 
questionnaire survey also took into account the period of employment of surveyed employees of Polish enterprises as a factor determining the evaluation of the superior by employees.

\section{Manager in a Modern Organisation}

One of the most important factors determining efficient functioning of an economic organisation is management, which consists in triggering and coordinating actions in line with team objectives. A manager is responsible for managing activities that lead to achievement of an enterprise's objectives. In order to fulfil a managerial function, one has to hold a formally established managerial position with an appropriate scope of tasks, powers and responsibilities entitling managers to make decisions to control the behaviour of the subordinates (Pocztowski, 2007). Niesyty (2009) stresses that in modern organisations a manger is at the same time a director, and the person who designates them for this role is the owner of the capital brought into the organisation, or sometimes its founder and initiator. Nowadays, most organisations are run by managers. The profession of a manager appeared with the emergence of an enterprise, once ownership became separated from management, when the owner was not able to control all problems connected with the functioning of an organisation and hired a professional to manage it (Mendel, 2006). According to Drucker (1998), most managers are directors, although these are not always synonymous terms, as a manager is somebody who, making their contribution to the final results of a company, takes responsibility for them (Bartkowiak, 2003). Penc (2005; 2007; Tomaszuk, 2013) defines a manager as everyone who is responsible in a company for fulfilling the function of management - a person who plans, makes decisions, organises, motivates people and controls the use of resources and achieved results. In literature on management the terms manager and director are often treated as almost synonyms, therefore in this paper they will be used interchangeably.

The basic characteristics of the work of a manager include specific functions, contribution brought into an organisation and such features as high skills and strong motivation, which allow them to integrate resources: material, financial and human ones, in order to perform business processes (Pocztowski, 2007). By using their skills and competences, managers encourage employees to work as a team, which underlies employees' creativity and produces innovative solutions. Appropriate support by a manager helps to create climate which motivates employees to effectively implement the company's objectives and successfully integrate with the company. As Stefanovska-Petkovska and others (2015) show, employees' participation in managing an organisation increases their job satisfaction, which leads to decreased absence and increased motivation, performance and self-assessment. What distinguish the work of people managing the work of other people are specific functions and roles fulfilled by them in an organisation and necessary skills. Literature on organisation and management distinguishes three basic groups of skills of a manager (Koontz, 2010; Cho' \& Poister, 2014):

- technical, i.e. knowledge of the tasks, processes and methods for solving problems in the area of managers' responsibilities,

- interpersonal (social), i.e. motivation, communication, teamwork, understanding other people;

- Connectional and diagnostic, i.e. analysing problems, abstract thinking, introducing changes.

The importance of specific skills may change - the higher the position in an organisation's hierarchy, the more important is the role of connectional skills. Technical skills are necessary at the lowest level of the organisational hierarchy.

Table 1: Roles of managers at the strategic level

\begin{tabular}{ll}
\hline Roles of managers & Characterisation \\
\hline Executor & $\begin{array}{l}\text { Active participation of line managers in the process of recruitment and } \\
\text { development of employees; they communicate with employees, passing strategic } \\
\text { objectives to them; the extent to which they involve employees in decision-making } \\
\text { impacts the effectiveness of the personnel strategy. }\end{array}$ \\
& $\begin{array}{l}\text { They can, among other things: define the desired human capital profile of their } \\
\text { employees; propose an appropriate form of work organisation; define objectives for } \\
\text { Initiator } \\
\text { their team and select measures for assessment of their achievement; propagate } \\
\text { quality philosophy among their employees and identify employees with high }\end{array}$
\end{tabular}


potential for development.

Active support for employees in matters connected with the work they perform and

Mentor

their professional development. A line manager, who gives factual and emotional support to employees and is sensitive to ethical issues, influences the development of human capital.

Source: (Pocztowski, 2007)

Every manager, irrespective of the organisation in which they work, fulfils a relatively wide range of roles in order to achieve established objectives. Managers strive to use market opportunities and ensure success to their organisations, uniting employees and resources around these objectives (Lichtarski, 2008). Mintzberg (after: Koontz, 2010) distinguishes ten basic managerial roles in three categories, namely: interpersonal roles (representative, leader, liaison), informational roles (observer, propagator, spokesman) and decision-making roles (entrepreneur, person preventing interruptions, assigning resources, negotiator). Managers should also be active at the strategically level of an organisation, fulfilling specific roles: executor, initiator and mentor (table 1). The profile of a manager is constantly changed, improved and modified. An important role is naturally played by such factors as the size and structure of a team, type of responsibility and entitlement to make decisions, the significance of performed tasks relative to the result of an organisation, organisational culture and climate (Tomaszuk, 2013). An attempt to create one, universal classification of a manager's roles is a mistake, as the same expectations from every manager may be in contradiction with the needs of a specific organisation and its strategic objectives. A manager of an organisation should create conditions that will allow a team of employees to pursue and achieve established objectives (Daft, 2014). The role of a manager cannot be limited to organisational processes. Their task is to create an environment of mutual respect for the other, create space that allows employees to be part of an organisation and its external initiatives (Quiros, 2013).

Manager as a leader: It is often indicated that the key to a company's success is effective leadership, which involves: creating a vision, implementing objectives, ambition, self-awareness, ability to establish relations and bonds. Leadership helps to establish boundaries, give employees appropriate competences and necessary support (Daft, 2014). The modern manager should be a leader. Blake and McCanse (1991) pointed out that an organisation's success can be achieved with minimal resources: financial, material and human ones, if there is effective leadership. Bryman (1992) stresses that we have to consider three aspects of leadership:

- leaders' impact on people's behaviour,

- the group the leader is in charge of,

- the objectives that should be achieved.

The essence of leadership is thus interactions between members of different teams and organisations that lead to achievement of objectives. The process of the development of leadership is constant improvement that never ends (Delmatoff \& Lazarus, 2014). Therefore, modern managers should develop such characteristics as: effective communication skills, constant readiness for changes, focus on achieving results, and a very important characteristic that gives competitive advantage - ability to continuously and quickly learn new behaviours, technologies and ways of acting.

Lyons (2000) distinguishes seven skills predisposing a person to being a leader, rather than only a manger (Tomaszuk, 2013):

- personal reflectiveness that allows a person to feel control on a continuous basis while verifying the plans and constantly identifying alternative solutions, which increases confidence and trust in oneself;

- ability to have a constructive dialogue that changes the subordinate/superior relationship into conversation between equal partners that leads to effective and direct cooperation;

- ability to define and identify the range of currently fulfilled roles both by oneself and in relation to subordinates, which also contributes to partnership-based relations and cooperation;

- ability to gain support, especially from specialists in other fields, which minimises the risk of lack of acceptance of a specific action by co-workers;

- $\quad$ courage to take new and risky actions; 
- ability to show recognition for a well-performed task;

- ability to analyse and verify introduced changes, continuously improve activities.

According Gorzeń-Mitka (2013) growing awareness of the role of risk in business activities, however, leads to searching new knowledge about risk identification tools, especially among the companies forming the core of any economy (SMEs). When a leadership style is defined, it is important to consider abilities to solve problems, disputes and conflicts (Nadler \& Tushman, 1999). A manager can impose a solution on the groups they manage, leave it to the group to find a solution or find another, much better solution (Hill et al., 2014), and by adjusting the leadership style to the existing conflict, a problem can be successfully solved (Swinton, 2008). Leadership theories have evolved over time. We cannot, however, distinguish the best management style. Efficient and effective management of resources requires appropriate competences to perform tasks and adapt to a specific situation. This led to the emergence of a situational leadership in management. Academic literature also distinguishes the so called leadership based on emotional and social intelligence (referred to by Goleman et al. (2002) as "contagion") (ESI) (Hughes \& Terrell, 2007). Reliance on the theory of emotional intelligence develops through emotionally intelligent leaders, who invoke positive emotions. Negative emotions cause the effect of dissonance, which brings the opposite effect (Delmatoff \& Lazarus, 2014).

We can also find references to transactional and transformational leadership. Transactional leadership requires that subordinates perform their tasks, but it offers appropriate rewards. Transformational leadership involves individual treatment and intellectual stimulation. A superior motivates subordinates to think creatively by inspiring those (Daft, 2014). It should be however stressed that according to Bass (1990), the best leaders should have both transactional and transformational skills, as transformational and transactional leaderships are not separate concepts, but are positioned at the opposite ends of continuum. Summing up, management of the modern enterprise requires that the person of a manager is transformed into a leader, who should personally: build a vision and present it to employees, create a strategy and mentality appropriate for the enterprise, make sure that the company's image is the best possible, and appoint people to managerial positions (Bogdanienko, 2004).

\section{Methodology}

Inference was based on findings of own research conducted in January 2015. The survey had the form of a questionnaire and was conducted on a group of 158 employees in enterprises carrying out their activity in four voivodeships of Poland. The respondents included employees of very small, small, medium-sized and large enterprises. The survey used purposive research sampling. The research tool was a survey questionnaire composed of 13 closed questions. Some questions were formulated using five-point Likert scale, which made it possible to obtain a more detailed opinion of those surveyed. Diagnosis of gathered data regarding the evaluation of the person of the superior took into account such variables as: the size of an enterprise (the employment figure in a given enterprise - categorisation adopted in the European Union), age of an enterprise (how long a company has been functioning on the market), period of employment of an employee (how long an employee has been working in a given enterprise) and the type of economic activity: manufacturing, trade and services. The following research problems have been formulated:

- Do the employment figure and age of an enterprise affect how employees evaluate their subordinates?

- How does the employment period of an employee in a given organisation affect the evaluation of the person of the superior?

- Does the profile of the economic activity of an enterprise affect how employees of an organisation evaluate their superior?

Based on received data, correlation coefficients have been calculated. For examining the relationships between the evaluation of the person of the superior and such characteristics as: the number of employees, how long a company has been functioning on the market and how long an employee has been working in a given enterprise, Kendall tau rank correlation coefficients were used. The distribution of received answers depending on the profile of an enterprise's activity was analysed using Kruskal-Wallis test and post-hoc Dunn's test. Test probability $\mathrm{p}<0.05$ was considered as significant, whereas test probability $\mathrm{p}<0.01$ was considered as highly significant. The results were analysed using the statistical application PQStat ver. 1.6. 
The findings of empirical studies presented in the paper constitute only part of wider studies of selected elements of an organisation management and should be treated as pilot research, as the research sampling is not fully representative. However, the size of the study group makes it possible to draw initial conclusions and find regularities that can be verified in the course of the proper research.

Characterisation of the Study Group: The employees surveyed were mainly employed in small and medium-sized companies, which accounted for over $3 / 4$ of all the enterprises, with very small companies, i.e. employing up to 9 employees, dominating in this group. Over half of those companies, almost $66 \%$, have been functioning on the market for over 10 years. Enterprises entering the market, i.e. functioning on it not longer than one year, accounted for only $2.5 \%$.

Table 2: Characterisation of enterprises employing the respondents $(n=158)$

\begin{tabular}{lll}
\hline Selected characteristics & & $\begin{array}{l}\text { Number } \\
\text { indications }\end{array}$ \\
\hline & micro (0-9) & 52 \\
Size of an enterprise (number of employees) & small $(10-49)$ & 42 \\
& medium (50-249) & 26 \\
& large (250 and more) & 38 \\
How long a company has been functioning on the market & up to 1 year & 4 \\
& $1-5$ years & 20 \\
& $5-10$ years & 30 \\
How long the respondents have been employed in a given & over 10 years & 104 \\
enterprise & up to 1 year & 50 \\
& 5 - 5 years & 62 \\
& over 10 years & 20 \\
Basic type of a company's activity & manufacturing & 26 \\
& trade & 40 \\
& services & 26 \\
& other/mixed & 58 \\
\hline
\end{tabular}

Source: Own work based on a survey

As far as the basic profile of activity is concerned, services enterprises accounted for almost $37 \%$ of the total study group, manufacturing enterprises constituted $1 / 4$, whereas commercial companies $-16.5 \%$. The mixed type of activity was also indicated, with entities of this type constituting $21.5 \%$ of the total (commercial and services companies were the most numerous). Employees working in a given company not longer than a year constituted quite a numerous group among those surveyed, accounting for $31 \%$ of all the respondents. Almost $40 \%$ of those surveyed were employed in a given organisation for over a year but not longer than 5 years. Only $16.5 \%$ of those surveyed indicated period of employment longer than 10 year (table 2).

\section{Findings}

Table 3: Assessment of different characteristics of a superior depending on the size of a company

\begin{tabular}{lll}
\hline Characteristics of a superior & tau & p \\
\hline has competences appropriate to the position held & -0.0358 & 0.5067 \\
is just, does not favour anybody & -0.0720 & 0.1820 \\
is honest toward subordinates & -0.0764 & 0.1568 \\
respects the opinion of the team & -0.0602 & 0.2646 \\
thinks that he/she has the greatest power (is the most important) & -0.0211 & 0.6961 \\
appreciates employees (uses rewards) & 0.0188 & 0.7270 \\
cares about positive atmosphere at work & -0.1210 & 0.0249 \\
actively participates in the work of the team & -0.0274 & 0.6112 \\
is not interested in subordinates & -0.1130 & 0.0363 \\
\hline
\end{tabular}

Source: Own work based on a survey 
As far as the length of functioning of an enterprise on the market is concerned, the survey found out this variable to be statistically significant $(p<0.05)$ and highly significant $(p<0,01)$ negatively correlated with the assessment of superiors in the following areas "possession of competences appropriate for the position held", "is fair, does not favour anybody", "is honest to the subordinates", "respects the opinion of the team", "appreciates employees (uses rewards)", cares about positive atmosphere at work" and "actively participates in the work of the team"(table 4). For the purpose of own research, nine features characterising the person of a superior (an enterprise's manager, leader or director who has got direct contact with employees) were selected. The respondents assessed their superiors relatively poorly on a five-point scale - the overall score was 3.56. The highest score, and the only one above four points, was given to competences of the superior the average score was 4.14. Other characteristics were assessed as follows: honesty towards subordinates (the average score of 3.91), fairness and lack of favouritism (the average score of 3.87) and active participation in the work of the team (the average score of 3.77). A similar average score (3.63) was received by the characteristic: respecting the opinion of the team and caring about positive atmosphere at work. The lowest weight was assigned to lack of interest in the subordinates - the average score of 2.40 on the scale. This is positive information, showing that employees notice their superiors' interest in them. The survey also showed that in the selected set of characteristics describing the superior, only two: "cares about positive atmosphere at work" and "is not interested in the subordinates" were found out to be statistically significant $(p<0.05)$ and negatively correlated at quite a low level with the variable of the size of an enterprise, expressed in the number of employees. The survey showed that the bigger the number of employees in an enterprise, the less interested is the superior in the employees and the less focused on good atmosphere at work (table 3 ). The other characteristics describing a superior were found out to be statistically insignificant and it is hard to determine whether these characteristics would be given to describe a superior in larger or smaller companies.

Table 4: Assessment of selected characteristics of the superior vs. how long a company has been functioning on the market

\begin{tabular}{lll}
\hline Characteristics of a superior & tau & p \\
\hline has competences appropriate to the position held & -0.1628 & 0.0026 \\
is just, does not favour anybody & -0.1462 & 0.0068 \\
is honest toward subordinates & -0.1801 & 0.0008 \\
respects the opinion of the team & -0.2084 & 0.0001 \\
thinks that he/she has the greatest power (is the most important) & 0.0457 & 0.3971 \\
appreciates employees (uses rewards) & -0.2021 & 0.0002 \\
cares about positive atmosphere at work & -0.2514 & 0.0000 \\
actively participates in the work of the team & -0.1075 & 0.0464 \\
is not interested in subordinates & -0.0674 & 0.2119 \\
\hline
\end{tabular}

Source: Own work based on a survey

One can thus conclude that the longer an enterprise has been functioning on the market, the less the superior cares about positive atmosphere at work - this characteristic shows the strongest negative correlation (tau=$0.2514)$ - the less he/she respects the opinion of the team (tau=-0.2084), the less he/she appreciates employees (the use of rewards is less frequent) (tau=-0.2021) and the less fair he/she is towards his/her subordinates (tau=-0.1801) (table 4).

Table 5: Assessment of the selected characteristics of the superior vs. how long an employee has been working in a given company

\begin{tabular}{lll}
\hline Characteristics of a superior & tau & p \\
\hline has competences appropriate to the position held & 0.0257 & 0.6341 \\
is just, does not favour anybody & -0.0597 & 0.2687 \\
is honest toward subordinates & -0.1627 & 0.0026 \\
respects the opinion of the team & -0.1907 & 0.0004 \\
thinks that he/she has the greatest power (is the most important) & 0.1137 & 0.0352 \\
appreciates employees (uses rewards) & 0.0063 & 0.9070 \\
\hline
\end{tabular}




\begin{tabular}{llc}
\hline cares about positive atmosphere at work & -0.0988 & 0.0672 \\
actively participates in the work of the team & -0.0051 & 0.9249 \\
is not interested in subordinates & -0.0271 & 0.6159 \\
\hline
\end{tabular}

Source: Own work based on a survey

The survey shows how employees assess their subordinate in relation to how long they have been working in a given company. Two of the selected characteristics of the superior were found out to be statistically highly significant $(\mathrm{p}<0.01)$ and negatively correlated at quite a low level with the period of employment of those surveyed in a given organisation. Statistically significant $(\mathrm{p}<0.05)$ and positively correlated at a low level is the characteristic: "he/she thinks that he/she has the greatest power (is the most important)", which confirms statistically significant earlier characteristics of the superior. Thus, according to those surveyed, the longer they work in a given enterprise, the more important their superior considers him/her to be, the less he/she respects the opinion of the team and the less honest he/she becomes towards the subordinates (table 5).

Table 6: Assessment of characteristics of the superior depending on the activity profile of a company

\begin{tabular}{|c|c|c|c|}
\hline Characteristics of a superior & $\begin{array}{l}\text { Type of a company's } \\
\text { activity }\end{array}$ & $\begin{array}{l}\text { Average } \\
\text { score }\end{array}$ & $\begin{array}{l}\text { Test Kruskala- } \\
\text { Wallisa }\end{array}$ \\
\hline $\begin{array}{l}\text { has competences appropriate to the } \\
\text { position held }\end{array}$ & $\begin{array}{l}\text { in total } \\
\text { manufacturing } \\
\text { Trade } \\
\text { Services } \\
\text { other/mixed }\end{array}$ & $\begin{array}{l}4.14 \\
4.30 \\
3.92 \\
4.03 \\
4.56\end{array}$ & $\begin{array}{l}H=4.93 \\
p=0.1769\end{array}$ \\
\hline is just, does not favor anybody & $\begin{array}{l}\text { in total } \\
\text { manufacturing } \\
\text { Trade } \\
\text { Services } \\
\text { other/mixed }\end{array}$ & $\begin{array}{l}3.87 \\
4.00 \\
3.62 \\
3.86 \\
4.00\end{array}$ & $\begin{array}{l}H=1.15 \\
p=0.7646\end{array}$ \\
\hline ishonesttowardsubordinates & $\begin{array}{l}\text { in total } \\
\text { manufacturing } \\
\text { Trade } \\
\text { Services } \\
\text { other/mixed }\end{array}$ & $\begin{array}{l}3.91 \\
3.95 \\
3.92 \\
3.86 \\
4.00\end{array}$ & $\begin{array}{l}H=1.05 \\
p=0.7901\end{array}$ \\
\hline respects the opinion of the team & $\begin{array}{l}\text { in total } \\
\text { manufacturing } \\
\text { Trade } \\
\text { Services } \\
\text { other/mixed }\end{array}$ & $\begin{array}{l}3.63 \\
3.65 \\
3.69 \\
3.50 \\
4.00\end{array}$ & $\begin{array}{l}H=1.01 \\
p=0.7993\end{array}$ \\
\hline $\begin{array}{l}\text { thinks that he/she has the greatest } \\
\text { power (is the most important) }\end{array}$ & $\begin{array}{l}\text { in total } \\
\text { manufacturing } \\
\text { Trade } \\
\text { Services } \\
\text { other/mixed }\end{array}$ & $\begin{array}{l}3.15 \\
3.20 \\
2.85 \\
3.31 \\
2.89\end{array}$ & $\begin{array}{l}H=2.82 \\
p=0.4209\end{array}$ \\
\hline appreciatesemployees (usesrewards) & $\begin{array}{l}\text { in total } \\
\text { manufacturing } \\
\text { Trade } \\
\text { Services } \\
\text { other/mixed }\end{array}$ & $\begin{array}{l}3.46 \\
3.35 \\
3.62 \\
3.42 \\
3.67\end{array}$ & $\begin{array}{l}H=1.52 \\
p=0.6766\end{array}$ \\
\hline cares about positive atmosphere at work & $\begin{array}{l}\text { in total } \\
\text { manufacturing } \\
\text { Trade } \\
\text { Services } \\
\text { other/mixed }\end{array}$ & $\begin{array}{l}3.63 \\
3.80 \\
3.77 \\
3.44 \\
3.78\end{array}$ & $\begin{array}{l}\mathrm{H}=4.34 \\
\mathrm{p}=0.2271\end{array}$ \\
\hline $\begin{array}{l}\text { actively participates in the work of the } \\
\text { team }\end{array}$ & $\begin{array}{l}\text { in total } \\
\text { manufacturing }\end{array}$ & $\begin{array}{l}3.77 \\
3.80\end{array}$ & $\begin{array}{l}H=5.74 \\
p=0.1248\end{array}$ \\
\hline
\end{tabular}




\begin{tabular}{llll}
\hline & Trade & 3.23 & \\
Services & 3.94 & \\
& other/mixed & 3.78 & \\
in total & 2.40 & \\
& manufacturing & 2.10 & $\mathrm{H}=15.72$ \\
& Trade & 1.62 & $\mathrm{p}=0.0013$ \\
& Services & 2.86 & \\
\hline
\end{tabular}

Source: Own work based on a survey

Further analysis took into account the main activity profiles of enterprises in which the respondents were working. Using the division of economic activity of enterprises into manufacturing, trade and services, it can be noticed that employees of manufacturing companies assigned the highest average weight to such characteristics of their superiors as: correspondence of the superior's competences with the position held (4.30), fairness and lack of favouritism (4.00), honesty towards subordinates (3.95) and care about positive atmosphere in the organisation (3.80). In the case of commercial companies, the superior received the highest average score on respecting the opinion of the team (3.69). The superior in services companies received the highest average scores on active participation in the work of the team (3.94), regarding himself/herself the most important in the organisation (3.31) and lack of interest in the subordinates (2.86). It's worth highlighting the lowest average in the case of the last two of the above-mentioned characteristics, as it shows that the superior is perceived as a person that is interested in subordinates and does not emanate the power associated with his/her position. The lowest average scores for these characteristics of superiors were observed in commercial companies (table 6).

The survey and analyses show that the results of the assessment of the superior on a 5-point Likert scale in terms of the characteristic "is not interested in subordinates" show highly significant differences $(\mathrm{p}=0.0013)$ across different groups of enterprises in terms of the type of economic activity (table 5). The highest average score (2.86) was observed in services companies and was significantly higher than the score of 2.10 for manufacturing companies $(\mathrm{p}=0.0452)$ and the score of 1.62 for commercial companies $(\mathrm{p}=0.0019)$. In the case of the other assessed characteristics of superiors, i.e. "has competences appropriate for the position held", "is fair, does not favour anybody", "is honest to subordinates", "respects the opinion of the team", "thinks that he/she has the greatest power (is the most important)", "appreciates employees (uses rewards)", "cares about positive atmosphere at work" and "actively participates in the work of the team", no significant differences were identified across groups distinguished by the type of activity (table 6).

\section{Conclusion}

The aim of the questionnaire survey was to indicate the main characteristics of a superior and his/her leadership skills in the area of managing employees, and to determine relationships between selected characteristics and the scale and activity profile of a company, how long it has been functioning on the market and period of employment of those surveyed. The results of the survey show that:

- the bigger the number of employees in an enterprise, the less interested is the superior in the employees, and the less he/she cares about good atmosphere at work;

- as the period of functioning of an enterprise on the market increases, the superior: cares less about positive atmosphere at work, is less respectful to the opinion of the team, less appreciates employees (uses rewards less frequently) and becomes less honest towards his/her subordinates; moreover,

- the assessment of the superior according to employees varies depending on their period of employment in a given organisation; the longer the period of employment of an employee, the worse the superior is assessed for his/her honesty towards subordinates, respecting the opinion of subordinates and attachment to power (thinks he/she is the most important).

- the superior of those surveyed is the least interested in subordinates in services companies; it was found out that the overwhelming majority of characteristics of a superior were not significant statistically across manufacturing, commercial and services companies. 
Analysis of the survey results allowed the questions formulated as part of the research problems in this paper to be answered. It is however worth considering conducting similar survey on a bigger population in order to identify regularities and present recommendations to leaders and managers of enterprises conducting economic activity not only across Poland.

\section{Reference}

Bartkowiak, G. (2003). Skuteczny kierownik - model i jego empiryczna weryfikacja, Wydawnictwo Akademii Ekonomicznej w Poznaniu, Poznań.

Bass B. M. (1990). From transactional to transformational leadership: Learning to share the vision. Organizational Dynamic, 18(3), 19-31.

Blake, R. R. \& McCanse, J. S. (1991). Leadership Dillemmas - Gird solutions. Gulf Publishing, Company, Houston.

Bogdanienko, J. (2004). Innowacyjność przedsiębiorstw, Wydawnictwo Uniwersytetu Mikołaja Kopernika, Toruń.

Bryman, A. (1992). Charisma and Leadership in Organizations, Sage Publication, London.

Cho, Y. J. \& Poister, T. H. (2014). Managerial Practices, Thrust Leadership, and Performance: Case of the Georgia Department of Transportation. Public Personnel Management, 43(2), 179-196.

Daft, R. L. (2014). Management, South-Western, Cengage Learning, Masson.

Delmatoff, J. \& Lazarus, I. R. (2014). The Most Effective Leadership Style for the New Landscape of Healthcare. Journal of Healthcare Management, 59(4), 245-249.

Drucker, P. F. (1998). Praktyka zarządzania, Czytelnik Nowoczesność, Akademia Ekonomiczna w Krakowie.

Goleman, D., Boyatzis, R. E. \& McKee, A. (2001). Primal leadership: The hidden driver of great performance. Harvard Business Review, 79(11), 42-53.

Goleman, D., Boyatzis, R. E. \& McKee, A. (2002). Primal leadership: Realizing the Power of Emotional Intelligence. Harvard Business Review Press. Boston.

Gorzeń-Mitka, I. (2013). Risk identification tools - Polish MSMES company's practices. Problems of Management in the 21st Century, 7, 6-11.

Hill, L. A., Brandeau, G., Truelove, E. \& Lineback, K. (2014). Collective Genius: The Art and Practice of Leading Innovation. Harvard Business Review Press, 2, 18-19.

Hughes, M. \& Terrell, J. B. (2007). The Emotionally Intelligent Team: Understanding and Developing the Behaviors of Success, John Wiley \& Sons, San Francisco.

Jarmołowicz, W. \& Kościński, M. (2005), Menedżerowie a kapitał społeczny organizacji. Nierówności społeczne a wzrost gospodarczy, 7, 31-45.

Koontz, H. (2010). Essentials of Management. An international perspective, Tata McGraw-Hill Education, New Delhi.

Kubik, K. (2012). Profesjonalizm menedżera determinantą sukcesu organizacji. Zeszyty Naukowe Uniwersytetu Przyrodniczo-Humanistycznego w Siedlcach Nr 93, Seria. Administracja i Zarzqdzanie, 20, 21-33.

Landau, J. (2009). When employee voice is met by deaf ears. SAM Advanced Management Journal, 74(1), 4-12.

Lichtarski, J. M. (2008). Ewolucja profilu kompetencyjnego kierownika, [in:] K. Krzakiewicz (ed.), Problemy pracy kierowniczej we współczesnym przedsiębiorstwie, Kreos, Poznań.

Lyons, L. (2000). Management is dead, People Management 26.

McKee, A. (2014). Retrieved from http://blog.teleosleaders.com/2014/07/25/when-fighting-with-your-bossprotect-yourself-first/ (on line: 05.07.2015).

Mendel, T. (2006). Kształtowanie potencjału i organizacja pracy własnej współczesnego menedżera, Wydawnictwo Akademii Ekonomicznej w Poznaniu.

Nadler, D. A. \& Tushman, M. L. (1999). The organization of the future: Strategic imperatives and core competencies for the 21st century. Organizational Dynamics, 28(1), 45-60.

Niesyty, E. (2009). Wpływ klimatu społecznego organizacji na jej sprawność, [in:] Z. Waśkowski (ed.), Sposoby budowania przewagi konkurencyjnej przedsiębiorstwa. Zeszyt Naukowy GWSHM nr, 1(3), 41-58.

Niklewicz-Pijaczyńska, M. \& Wachowska M. (2012). Wiedza - Kapitał Ludzki - Innowacje, Wydawca Prawnicza i Ekonomiczna Biblioteka Cyfrowa. 
Okręglicka, M. (2012). Investments of Small and Medium-Sized Enterprises in Poland and Sources of Their Financing in 2011, [in:] S. Hittmar (ed.), Regional Management - Theory, Practice and Development. Scientific Papers. EDIS, University Publishing House, University of Zilina.

Penc, J. (2005). Role i umiejętności menedżerskie. Sekrety sukcesu i kariery, Difin, Warszawa.

Penc, J. (2007). Pojęcie i zadania menedżera, [in:] E. Jędrych (ed.), Zarządzanie zasobami ludzkimi dla menedżerów średniego szczebla, Oficyna WoltersKluwer Business, Kraków.

Pocztowski, A. (2007). Zarządzanie zasobami ludzkimi, PWE, Warszawa.

Quiros, E. (2013). Creating an Environment for Your Team to Strive. Strategic Finance, 95(10), 20-22.

Stefanovska-Petkovska, M., Bojadziev, M. \& Mucunski, Z. (2015). Does participative management produce satisfied employees? Evidence from the automotive industry. Serbian Journal of Management, 10(1), 75-88.

Swinton, L. (2008). Workplace Conflict Management: Strategy for Successful Resolution, 5, 12. Retrieved from http://www.mftrou.com/support-files/workplace-conflict-management-strategy.pdf.

Tomaszuk, A. (2013). Sylwetka menedżera w świetle teorii zarządzania i badań własnych na przykładzie menedżerów sektora budownictwa województwa podlaskiego. Economics and Management, 4, 67-81. 